\title{
THE FEATURES OF THE COMPOSITION SEEN ON CERAMIC DISHES OF IZNIK AND UNDERGLAZE DECORATIONS
}

\author{
Ezgi GÖKÇE ${ }^{1}$, Can GÖKÇE ${ }^{2}$
}

\begin{abstract}
Iznik ceramics represent an amazing technical innovation in the history of Turkish ceramic art. In the $15^{\text {th }}-16^{\text {th }}$ century, following the establishment of the Ottoman Empire, the name of Iznik became famous throughout the world due to the development of a ceramics production. Combining the Ottoman style with external influences from China, Asia, the Balkans and even Europe, Iznik vessels and tiles reached their peak within the Ottoman ceramic art. The court's patronage stimulated and supported the development of an artistically and technically advanced ceramic industry in Iznik.In this study, the specific compositions on dishes and decoration pecularities of Iznik ceramics are introduced. Accordingly, it is intended to put forward the characterictis compositions and decoration techniques.
\end{abstract}

Keywords: Iznik Ceramics, ceramic dish, traditional arts, underglaze decoration.

Gökçe, Ezgi, Gökçe, Can. "İznik Seramik Tabaklarında Görülen Kompozisyonların Özellikleri Ve Siraltı Dekor Tekniği-The Features Of The Composition Seen On Ceramic Dishes Of Iznik And Underglaze Decorations ". idil 6.29 (2017): 367-384.

Gökçe, E., Gökçe, C. (2017). İznik Seramik Tabaklarında Görülen Kompozisyonların Özellikleri Ve Sıraltı Dekor Tekniği-The Features Of The Composition Seen On Ceramic Dishes Of Iznik And Underglaze Decorations. idil, 6 (29), s.367-384.

\footnotetext{
${ }^{1} Y r d$. Doç., Uşak Üniversitesi, Güzel Sanatlar Fakültesi, Geleneksel Türk El Sanatları Bölümü, ezgi.gokce(at)usak.edu.tr

${ }^{2}$ Öğr. Gör., Uşak Üniversitesi, Banaz Meslek Yüksek Okulu, El Sanatları Programı, can.gokce(at)usak.edu.tr
} 


\title{
IZNIK SERAMIK TABAKLARINDA GÖRÜLEN KOMPOZISYONLARIN ÖZELLIKLERI VE SIRALTI DEKOR TEKNIĞi
}

\begin{abstract}
ÖZ
İznik seramikleri, Türk seramik sanatı tarihinde bir teknik yeniliği temsil etmektedir. 15.-16. yüzyıllarda Osmanlı İmparatorluğunun kuruluşunu takiben; İznik, seramik üretiminin gelişmesi ile dünyaca ünlü hale gelmiştir. Osmanlı Döneminde Çin, Asya, Balkanlar ve hatta Avrupa'dan gelen diş etkilerle birleştirilen desenler, teknikler İznik seramik ve çinilerini zirveye taşımıştır. Saray himayesi, İznik'te seramik üretimini sanatsal ve teknik açıdan destekleyerek seramik endüstrisinin gelişimini sağlamışitır. Bu çalışmada, İznik seramik tabaklarında görülen desen ve komposizyon özellikleri tanıtılmıştır. Buna göre, karakteristik kompozisyon ve dekor tekniklerini ortaya koymak amaçlanmıştır.
\end{abstract}

Anahtar Kelimeler: İznik Seramikleri, seramik tabak, geleneksel sanatlar, sıraltı dekor tekniği. 


\section{History Of Iznik Ceramics and Their Characteristics}

Ceramic production in Iznik dates back to the $4^{\text {th }}$ century BC. It is thought that traditions of ceramic production in Mesopotamia, Egypt and Asia have effected ceramic production in Iznik. But Iznik gained the opportunity of proving itself especially after mid $-15^{\text {th }}$ Century as a result of technological improvements.(Bakır, 2007:280) The ceramics of Iznik ${ }^{3}$ which were produced in Ottoman era and which reached nowadays are generally classified in two groups as those produced out of red coloured clay and those produced out of fritted white clay. Especially for daily use; it is seen that slip applications and also colourful glazes were used in ceramics of the period between $14^{\text {th }}$ and $15^{\text {th }}$ centuries which were produced out of red clay. Such techniques indicate the connection between the Art of ceramics in Ottoman Era and Seljukian Era.(Bilgi, 2009:23) On the other side, what make the ceramics that are produced out of fritted white clay so attractive and so beautiful are their bodies and decorations. The body of such ceramics constitute of Granulated Quartz, Frit and white clay which improves the plasticity at a small amount. The body used while producing ceramics of Iznik, together with the colouring agents and the glazes, the colours and the patterns constitute the real focus for attractiveness. Deep cases, big cases with standing legs, flat plates with wide edges, plates with shredded edges, pitchers, vases, jars and oil-lamps are significant elements of ceramics of Iznik. Atasoy ve Raby (1989) has used tersm such as "Baba Nakkaş", "Düğüm Ustası", "Helezoni Tuğrakeş Üslûbu" for the pattern types observed on ceramics of Iznik since the era of Fatih Sultan Mehmet. Furthermore, the general methods that are observed in these ceramics can be examined under four general categories which correspond to four stages; and these four stages are stated to be corresponding to four periods of reign which follow each other. These stages are: the last decade of the reign of Fatih Sultan Mehmet (1451-1481), the reign of Sultan Bayezid the $2^{\text {nd }}(1481-1512)$, the reign of Sultan Selim the $1^{\text {st }}(1512-1520)$ and the first decade of the reign of Kanuni Sultan Süleyman (Suleiman the Magnificent) (15201566). The ceramics which were produced during the era of Fatih Sultan Mehmet are believed to be effected by blue-white ceramics of Chinese and metal works. ${ }^{4}$ Beside the

\footnotetext{
${ }^{3}$ For more information about the ceramics of Iznik: Atasoy, N., Raby, J., (1989). Iznik Seramikleri. London: Alexandria Press, Bilgi, H., (2009). Ateşin Oyunu: Sadberk Hanım Müzesi ve Ömer Koç Kolleksiyonlarından Iznik Çini ve Seramikleri, İstanbul: Vehbi Koç Vakfı Sadberk Hanım Müzesi Yayınları, Carswell, J. (1998) Iznik Pottery, London: British Museum Press, Lane, A. (1957), Later Islamic Pottery: Persia, Syria, Egypt, Turkey, Öney, G., Çobanlı Z., (2007) Anadolu'da Türk Devri Çini ve Seramik Sanatı, İstanbul: T.C. Kültür ve Turizm Bakanlığı Yayınları, Watson, O. (2005) Ceramics from Islamic Lands, New York.

${ }^{4}$ For more information: Atasoy, N., Raby, J. (1989). Iznik Seramikleri. London: Alexandria Press, Fehervari,G. (2000), Ceramics of the Islamic Lands, p.305-310, Stanley, T. (2011) "Iznik Ceramics Between Asia and Europe, 1470s-1550s", Arts of Asia, V. 41, no 6, p.123-132.
} 
patterns, it is the size and the colours used within the ceramics which support this theory. The patterns designed by muralists within the centre of muralists in Topkap1 were applied on the ceramics by the Masters of Iznik. In the beginning, curvy branches under dominancy of blue as a colour, patterns of rumi, lotus and palmet were used.

At the beginning, curved branches, Rumi, palmette and lotus motifs, which possesses blue-white colours, were used. An extensive workmanship draws the attention in the works of this period.(Atasoy, Raby, 1989:79) In the midst of the $16^{\text {th }}$ century, turquoise, then purple and green colours were seen in addition to the bluewhite colour that is seen on underglaze decoration of ceramics of Iznik. In this period qualified ceramics were produced. The white ground is very clean and solid, the glazes are colourless and transparent, the colours of the paintings are vivid and shiny. With the contribution of Ottoman palace atelier's effect and the patterns of wall ceramics that are ordered, the changes in ceramics of Iznik have been observed since the midst of the $16^{\text {th }}$ century. By adding fluffy (coral) red, the flowers such as roses, carnations, hyacinths, tulips and hatai and badges inform a new decoration style in which the naturalist tendency dominates (Demirsar, Altun, 2008:25). Rumi, Hatayi, cloud elements and animal figures appear on the ceramics of this period. In the art of Ottoman, the production of Turkish ceramic reached the highest quality level especially in the second period of the $16^{\text {th }}$ century. The new production gives few clues, for its designs are directly relatable in a stylistic sense to court taste and court ideas and clearly reflect an appeal to court patronage.(Denny, 2002:35-37) In the period from $14^{\text {th }}$ century to $20^{\text {th }}$ century, the ceramists of Ottoman period revealed styles of the period with the excitement of renovating and producing to which the Empire adds acceleration power in every period, however infrastructure, decoration techniques, patterns and colours used are.

“...Beginning from the earliest times of the Ottoman Empire to its classical and late times, the Ottoman art adopted a static mode of artistic production while its dynamics were dependent on a single center regarding the centralised structure of the state administration. Such a centralised conception of artistic production led the way to a unification of images and created unity in visual language. Thus, certain styles and modes were flourished in a collective manner shaped by the court's tastes and selected by the sultan. About the Ottoman court arts, the most effective factor in having a collective body and the interaction of diverse branches of art is that the arts were being produced inside the court..." (Toprak, Gökçe, 2014:2) 


\section{Forms of Ceramic Dishes of Iznık}

Dishes were the most common type of vessel made by the potters of Iznik and were produced in a great variety of shapes and sizes (Figure 1).

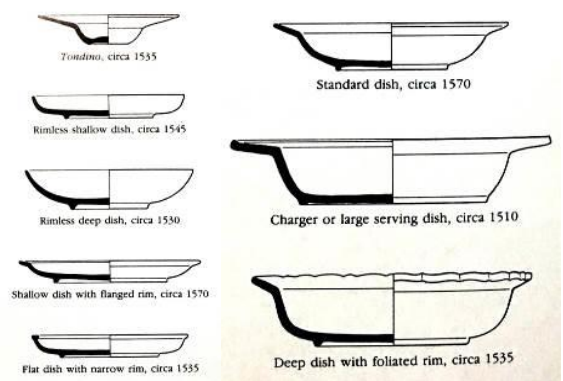

Figure 1: Some types of dishes, Atasoy, N., Raby, J. 1989, Iznık The Pottery of Ottoman Turkey, p.38.

\section{Underglaze Decorations}

Ceramics of Iznik are divided in specific categories in the compositions specified according to its styles. These sections are divided as style, composition and as a whole, they are divided in the elements that we identified as edge, cheek, border (Figure 2-3-4-5). In the compositions that shall be applied to the surfaces of styles, the motifs that aren't used alone generally are connected with each other in different location and direction. The different patterns and motifs are applied to the surfaces like body, neck, cheek, bottom in specific styles and measures at the given concentration. 


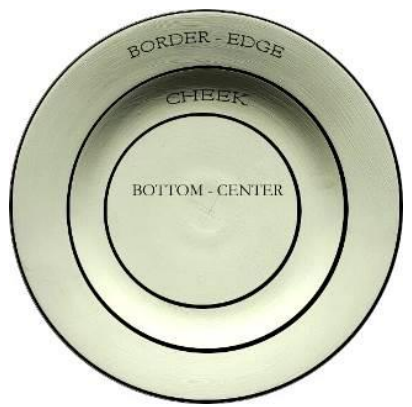

Figure 2: Plate Parts, Border-Edge, Cheek, Bottom-Center, Personal Archive.

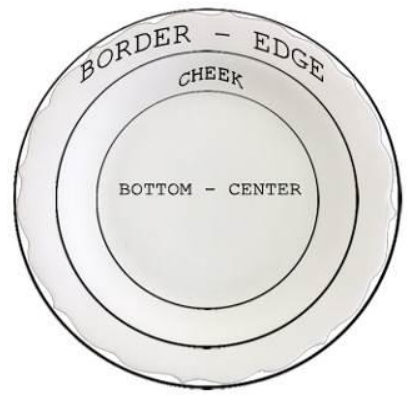

Figure 4: Plate Parts, Border-Edge, Cheek, Bottom-Center, Personal Archive.

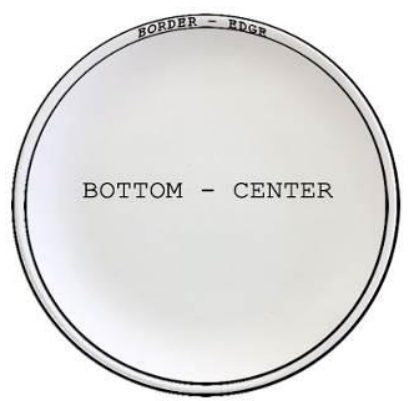

Figure 3: Plate Parts, Border-Edge, Cheek, Bottom-CenterPersonal Archive.

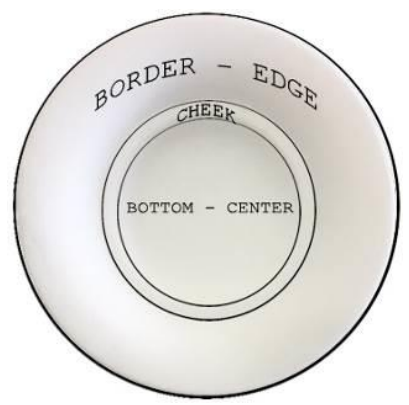

Figure 5: Plate Parts, Border-Edge, Cheek, Bottom-CenterPersonal Archive.

It is essential to establish a coherence between the composition and the motifs to be applied to the surface with shape, size, colour and balance correctly.

The palace atelier that reminds the educational institution in Ottoman period composed the pattern program of the products manufactures in Iznik. It is seen that the design principles are known and applied in these compositions. 
When the examinations that are done on the samples of Iznik ceramic plate decorations are considered; big-small relations in accordance with visual hierarchy, direction differences, the coherence between middle pattern and edge pattern, the usage of light and dark shades of the colours, ground-motif relation, adding motion and vitality with the illusions that are done to eliminate the monotony in repeating units, the usage of contrasts by forming a harmonious balance, providing the continuity of the motion by using colours that supports rhythm and balance and by spreading the emphasis around show that the designs of these patterns are done depending on specific rules.

\section{Symmetrical Compositions}

In this type of compositions; the pattern is designed on one side of a vertical line dividing the pattern in the exact middle, called as the middle axis. Then the paper is folded over the middle axis and the designed composition is copied on the opposite side to obtain a symmetrical pattern. Thus; composition integrity is ensured. However, in this style of compositions generally the symmetry is broken by making some changes, especially in size, in some motifs at the bottom part of the plate or some other parts (Figure 6-7).

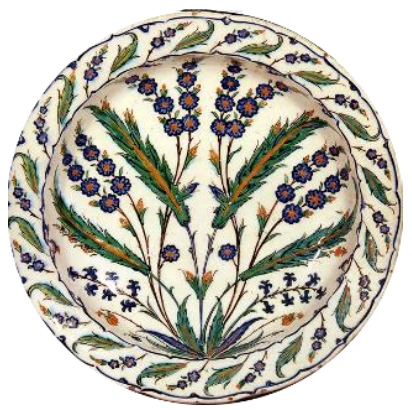

Figure 6:Iznik Dish 16th Century, Atasoy, N., Raby, J. 1989, Iznık The Pottery of Ottoman Turkey, p.297.

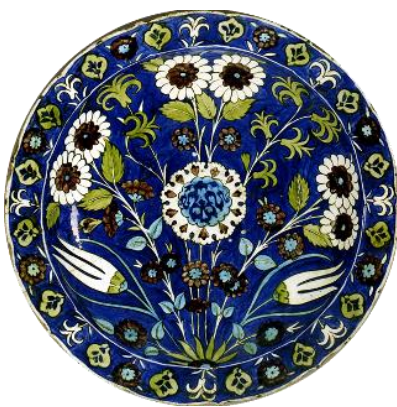

Figure 7: Iznik Dish 16th Century, Atasoy, N., Raby, J. 1989, Iznık The Pottery of Ottoman Turkey, p.204. 


\section{Asymmetrical and Free Compositions}

In this type of compositions, the motifs are placed in the entire dimension of the plate. Asymmetrical compositions constitute a very difficult composition type. It is widely used in motif arrangements featuring plants. The most beautiful samples of this composition type are seen in $16^{\text {th }}$ century classical patterns (Figure 8-9). Some examples for free composition from today (Figure 10-15).

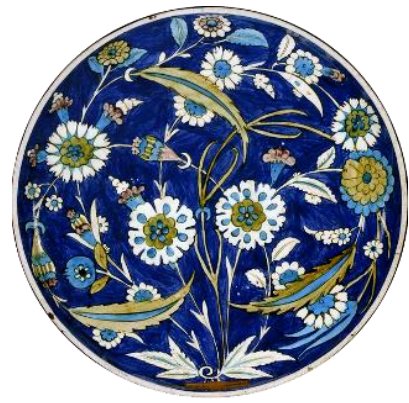

Figure 8: Iznik Dish 16th Century, Atasoy, N., Raby, J. 1989, Iznık The Pottery of Ottoman Turkey, p.206.

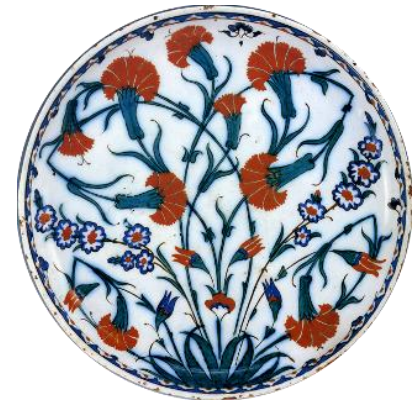

Figure 9: Iznik Dish 16th Century, Atasoy, N., Raby, J. 1989, Iznık The Pottery of Ottoman Turkey, p.310 


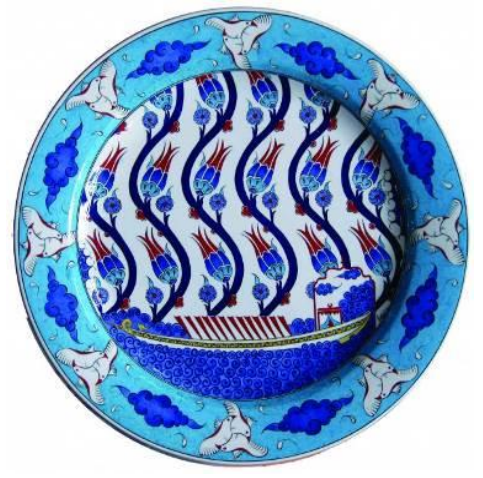

Figure 10: Can Gokçe's Artwork1 "Sultan Boat in Tulips", Free Composition, Decorated with Classical Underglaze Technique, (Ø: 82cm), Personal Archive.

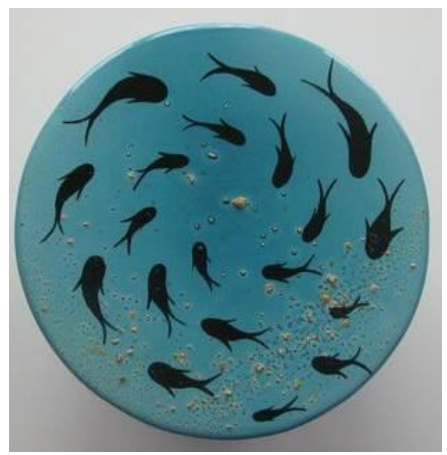

Figure 12: Ezgi Gokçe's Artwork1 "Seems like dish", Free Composition, Decorated with Classical Underglaze Technique, $(25 \times 25 \times 14 \mathrm{~cm})$, Personal Archive.

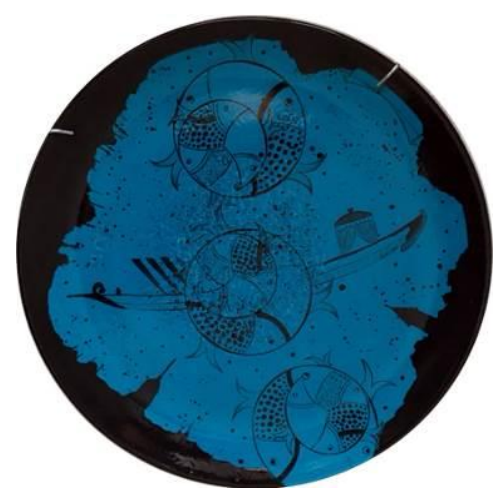

Figure 11: Can Gokçe's Artwork2 "Sultan Boat on Bosphorus", Free Composition Decorated with Classical Underglaze Technique, (Ø: $60 \mathrm{~cm})$, Personal Archive.

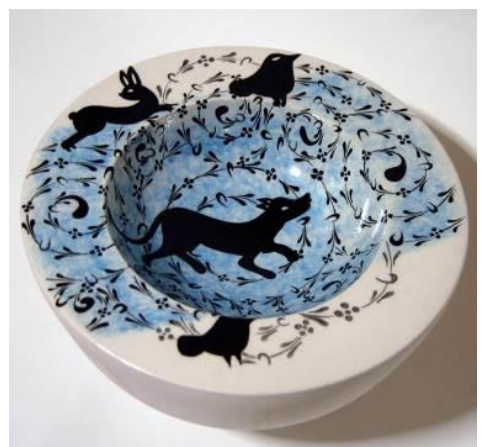

Figure 13: Ezgi Gokçe's Artwork2 "Dish-Like", Free Composition Decorated with Classical Underglaze Technique, $(30 \times 30 \times 25 \mathrm{~cm})$, Personal Archive. 


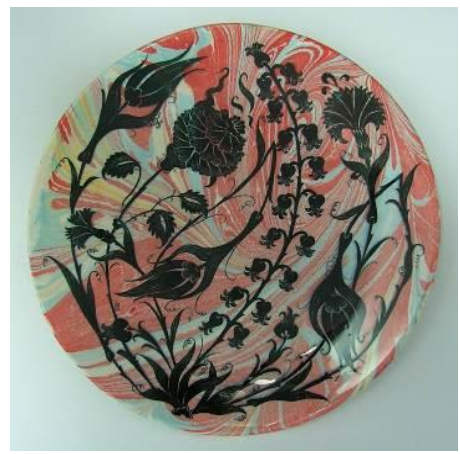

Figure 14: İ. Vefa İrdelp's Artwork1 "Marbling 1", Free Composition, Decorated with Underglaze Technique, (Ø: 30cm), Personal Archive.

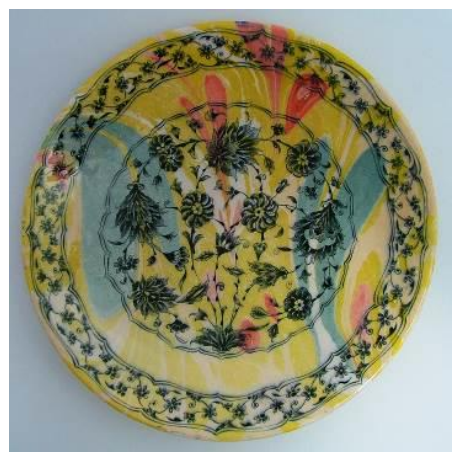

Figure 15: İ. Vefa İrdelp's Artwork2 "Marbling 2", Free Composition, Decorated with Underglaze Technique, (Ø:33cm), Personal Archive.

\section{Unicentric Compositions}

This type of composition is also called centrally developed composition. In this type of composition, the motifs forming the composition are all oriented to the centre (Figure 16-17).

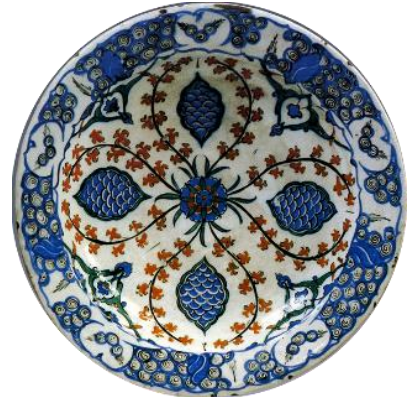

Figure 16: Iznik Dish 16th Century, Atasoy, N., Raby, J. 1989, Iznik The Pottery of Ottoman Turkey, p.312.

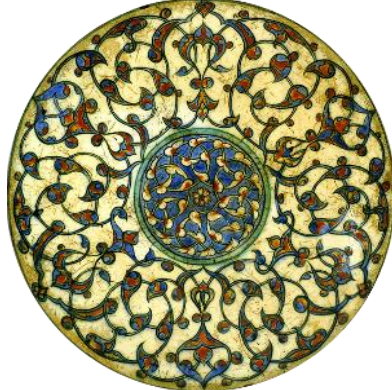

Figure 17: Iznik Dish 16th Century, Atasoy, N., Raby, J. 1989, Iznik The Pottery of Ottoman Turkey, p.216. 


\section{Multicentric Compositions}

This type of composition includes multiple arrangements. Each unit oriented around certain axes are again tied together in orientation to certain axes. In this arrangement each unit is linked to another in orientation to certain axes in order to form a whole (Figure $18-19$ ).

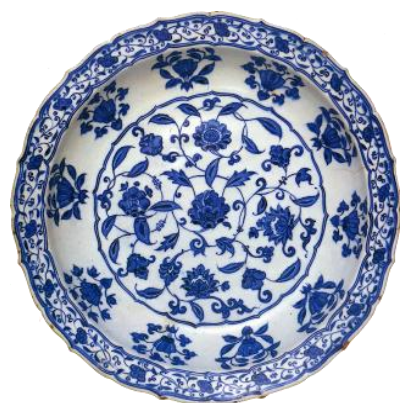

Figure 18: Iznik Dish 16th Century, Atasoy, N., Raby, J. 1989, Iznik The Pottery of Ottoman Turkey, p.186.

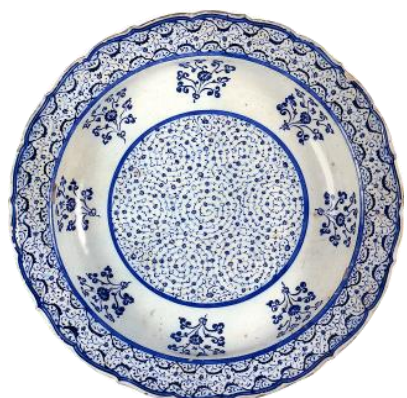

Figure 19: Iznik Dish 16th Century, Atasoy, N., Raby, J. 1989, Iznık The Pottery of Ottoman Turkey, p.175

\section{Underglaze Decoration Technique}

The pattern is drawn on parchment paper according to decoration form. When drawing the design first a general composition is formed with the general outlines of the pattern, and then all lines of the motifs are filled in (Figure 20-21-22). 


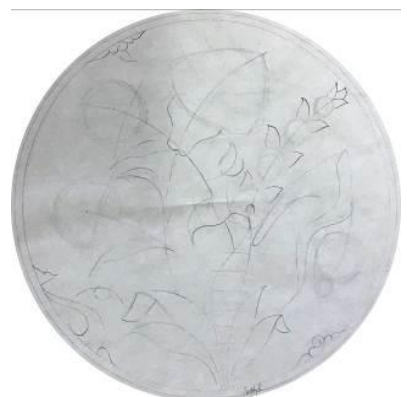

Figure 20: Preparing Composition for Plate on Parchment Paper, Can Gökçe's design, Personal Archive.

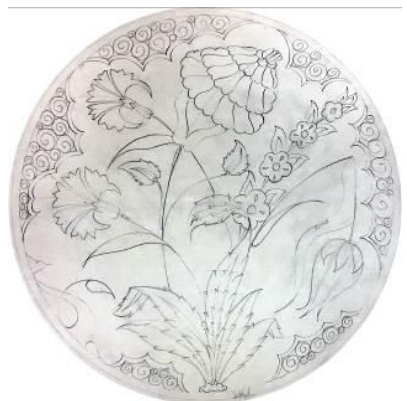

Figure 21: Detailed Composition for Plate on Parchment Paper, Can Gökçe's design, Personal Archive.

Figure 22: Detailing The Composition for Plate on Parchment Paper, Can Gökçe's design, Personal Archive.

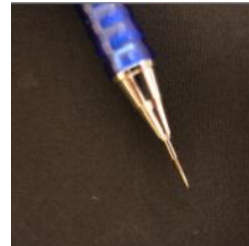

Figure 23: Detail of Pencil with Needle, Personal Archive.

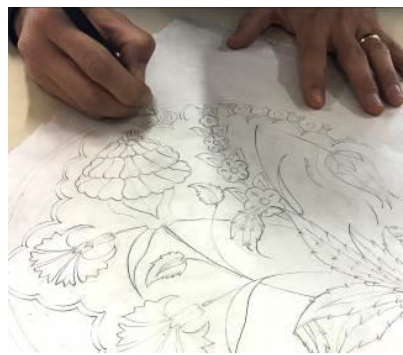




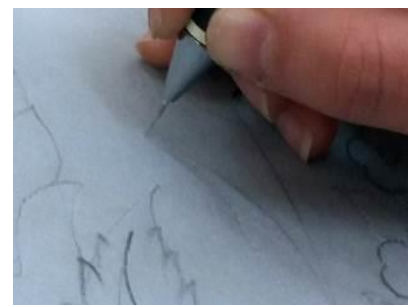

Figure 25: Detail of Piercing Design on Parchment, Personal Archive.

The drawn pattern is perforated by pins (generally by placing a bead pin in a mechanical pencil) and transferred to the form by using coal dust (Figure 23-25). The biscuit fired form must be first ground with fine sandpaper to obtain a smooth surface to ensure that the brush moves freely (Figure 26). The pattern transferred to the form by coal dust can also be drawn in by brush, but beginners may prefer to lightly draw over the pattern by a pencil (Figure 27). In ceramics the contour lines surrounding the motifs are drawn in black or blue, using a brush. This is called as "tahrir". In ceramics of Iznik essaying is performed with sable brushes (Figure 24). Generally number 3 sable brushes are used for this purpose, but number 2 and 4 brushes are also used for drawing outlines of motifs. Drawn outlines-contours include nuanced lining (thin-thick). Then motif painting stage begins.

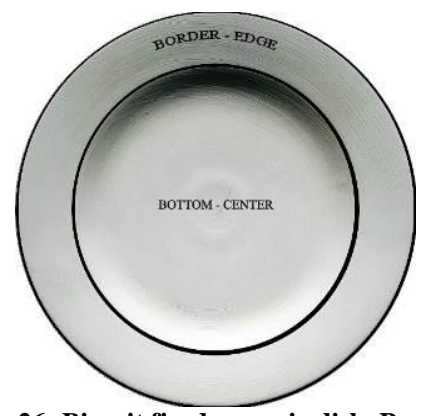

Figure 26: Biscuit fired ceramic dish, Personal Archive.

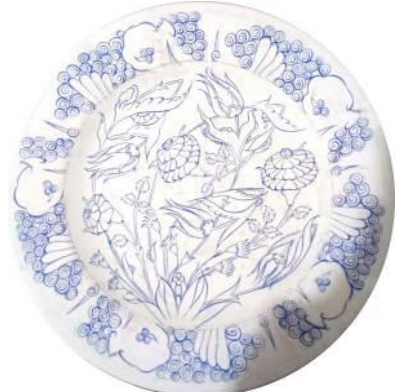

Figure 27: Drawn Contours of Motifs, Artworks of Tuğba Sarıpınar, Student at Usak University, Fine Arts Faculty. 
Today many colours are used for ceramic decoration. However the classical colours include black, blue, turquoise, green and red. There are various characteristics to use of these colours. Specially made horsehair brushes are used for painting (Figure 28-29).

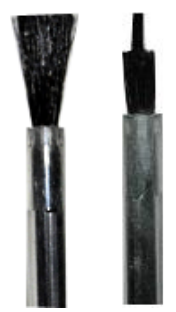

Figure 28: Horsehair and Cut Horsehair Brush, Personal Archive.

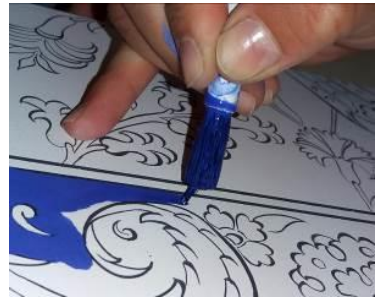

Figure 29:Using Horsehair brush, Personal Archive.

First, colours are determined for the areas and motifs to be painted. The balance of motif placement in composition is also very important in colouring phase. Colours should be distributed in a balanced fashion in order to maintain integrity of the pattern. In addition, it is known that certain colours and application methods are preferred for certain motifs and backgrounds in ceramic patterns.

Painting process starts with darker colours and proceeds in order towards lighter colours. Red colour is painted in multiple layers to provide embossment and to ensure the colour is clearly visible. During painting care should be taken to avoid overlap between different colours. Colours other than red are not opaque. Especially motifs using blue and green colours include shadowing (lighter-darker) application. Paint is diluted to lighten the colour. Starting painting with lighter shades allows for more control. After light colour application motif sections to be shadowed are repainted to darken the colour. Use of thick paint in decoration process can cause loss of lustre on the glazing or occurrence of metallic effects (in copper containing paints). Therefore care should be taken especially when applying shadowing effects. Turquoise paint must be applied in a thin and homogenous layer. Red paint should be applied in a thick and homogenous layer. Paint should be applied according to characteristics and intended use of each paint. Otherwise undesired appearances can be encountered after firing. 
In essayed patterns care should be taken to ensure that paints applied on determined motifs and backgrounds are applied in homogenous thickness and without corrugation according to characteristics and intended use of each paint. The paint is constantly mixed and transferred to the paint brush. The paint is prepared by using a mixture of oxide pigments, glaze and clay. Since the clay sinks to the bottom paint should be mixed from bottom to top at each brush dip.

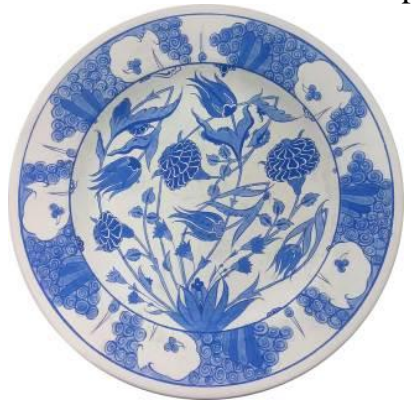

Figure 30: Decorated Ceramic (Berfore Glaze

Firing), Artwork of Tuğba Sarıpınar, Undergraduate Student at Usak University, Fine Arts Faculty.

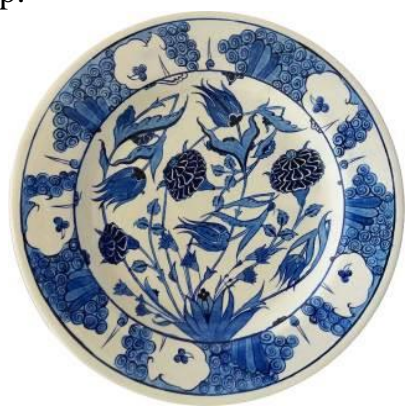

Figure 31: Decorated and Glazed Ceramic, Artwork of Tuğba Sarıpınar, Undergraduate Student at Usak University, Fine Arts Faculty.

Today the ceramic glaze is adjusted according to texture. Cracks and textureglaze incompatibility can be seen especially due to some raw materials and substances used in Kütahya from time to time. The glaze used in these in a low degree transparent glaze with alkali-lead content. Glazing temperature varies between 930 and $1050{ }^{\circ} \mathrm{C}$. 


\section{CONCLUSION}

The reason for the inability to produce ceramics of Iznik similar to the originals is the difficulty of finding written sources, or even total lack of written records. Ceramics of Iznik, and even their copies, are still one of the most valuable ceramic pieces of many museums, private collections and auction houses. Traditional ceramic production is field where expertise and experience are strict requirements. This heritage which holds such an important place in world ceramic history must be conveyed to future generations by sharing the knowledge and continuing production. The goal of this study remains promoting the cultural and artistic values of the Iznik ceramics, to promote the existing potential and transfer to future generations the traditional Iznik Ceramic Art through writing and producing. Today's ceramic artist who takes traditional ceramic education or training uses different techniques and makes new compositions. In this way, the tradition changes and also continues to live.

\section{REFERENCES}

Allan, J. W. (1973). “Abu'l-Qasim’s Treatise on Ceramics”, Iran, 11: 111-120.

Akar, A., Keskiner, C. (1978). Türk Süsleme Sanatlarında Desen ve Motif, Tercüman Sanat ve Kültür Yayınları, İstanbul.

Arlı, B. D., Altun, A. (2008). Anadolu Toprağının Hazinesi Çini Osmanlı Dönemi, İstanbul: Kale Grubu Kültür Yayınları.

Atasoy, N., Raby, J. (1989). Iznik The Pottery of Ottoman Turkey. London: Alexandria Press.

Bakır, S. T., (2007). "Osmanlı Sanatında Bir Zirve Iznik Çini ve Seramikleri”, Anadolu'da Türk Devri Çini ve Seramik Sanatı, ed. Gönül Öney- Zehra Çobanlı), İstanbul: T.C. Kültür ve Turizm Bakanlığı Yayınları. Bilgi, H. (2009). Ateşin Oyunu: Sadberk Hanım Müzesi ve Ömer Koç Kolleksiyonlarından Iznik Çini ve Seramikleri, İstanbul: Vehbi Koç Vakfı Sadberk Hanım Müzesi Yayınları. 
Birol, I. A., Çiçek D. (1995). Türk Tezyini Sanatlarında Motifler, 2. Baskı, Kubbealtı Neşriyatı, İstanbul.

Birol I. A. (2012). Klasik Devir Türk Tezyini Sanatlarında Desen Tasarımı, Kubbealtı Neşriyatı, Sanat Dizisi, İstanbul.

Carswell, J. (1998). Iznik Pottery, London: British Museum Press.

Denny, W. B. (1981). "Turkish Ceramics and Turkish Painting: The Role of the Paper Cartoon in Turkish Ceramic Production." In Essays in Islamic Art and Architecture in Honor of KatharinaOtto-Dorn, edited by Abbas Daneshvari. Malibu: Undena Publications.

Denny, W. B. (2002). "Painting on Ceramic." Studio Potter 31, no. 1 (December 2002): 35-37. Art Source, EBSCOhost (accessed April 26, 2016).

Denny, W. B. (2005). Iznik: The Artistry of Ottoman Ceramics, Thames\&Hudson Press. York.

Fehervari, G. (2000). Ceramics of the Islamic Lands, I.B. Tauris Publish, New

Keskiner,C. (2000). Türk Süsleme Sanatlarında Stilize Çiçekler-Hatai-, T.C.Kültür Bakanlığı Yayınları, Ankara.

Kürkman, G. (2006). Magic of Clay And Fire : A History of Kütahya Pottery And Potters. Istanbul: Suna and İnan Kıraç Foundation.

Lane, A. (1957). Later Islamic Pottery: Persia, Syria, Egypt, Turkey, London.

Necipoğlu, G. (1990). "From International Timurid to Ottoman: A Change in Taste in Sixteenth Century Ceramic Tiles." Muqarnas 7: 136-170.

Öney, G., Çobanlı Z. (2007). Anadolu'da Türk Devri Çini ve Seramik Sanatı, İstanbul: T.C. Kültür ve Turizm Bakanlığı Yayınları

Özkeçeci, I. (2014). Türk Sanatı'nda Kompozisyon, Yazıgen Yayınevi, İstanbul. 
Refik, A, (1932). "Iznik Çinileri (Hazinei Evrak Vesikalarına Nazaran)". Darülfünun Edebiyat Fakültesi Mecmuası, 8 (4): 36- 55.

Stanley, T. (2011). "Iznik Ceramics Between Asia and Europe, 1470s-1550s", Arts of Asia, V. 41, no 6, p.123-132,

Şahin, F. (1989). Türk Çini Sanatı Süslemeciliği, Anadolu Üniversitesi Yayınları.

Toprak, F., Gökçe, E. (2014). XVII. Yüzyıl Başı Osmanlı Kıyafet Albümlerinde ve İznik Seramiklerinde Sanat Üretimi Etkileşimi. Atatürk Üniversitesi Sosyal Bilimler Enstitüsü Dergisi, 18 (1), 89-104.

Watson, O. (2005). Ceramics from Islamic Lands, New York. 
